\title{
ELECTRONIC PRESCRIPTIONS TO IMPROVE PATIENT SAFETY IN HOSPITAL: A SYSTEMATIC REVIEW
}

\author{
Farida Apriani Utami, Mardiati nadjib \\ Department of Hospital Administration, Faculty of Public Health, Universitas Indonesia
}

\begin{abstract}
Background: E-Prescribing automates the manual prescription process which enables physicians, pharmacies and payers to gain access to information that contributes to patient safety, controlling costs, and gaining business intelligence. E-Prescribing eliminates handwriting errors/illegibility and gives both physician and pharmacist access to a patient's prescription history to reduce the chance of the wrong drug being dispensed. According to the FDA, more than 95,000 prescription drug errors have occurred since 2000, mainly due to mistakes when reading a handwritten prescription and dispensing a similar-sounding, but different drug.

Subjects and Methods: A systematic review was conduct by searching published articles from 2014 to 2019 from database including ProQuest, Cochrane, PubMed, and Scopus. The keywords were "electronic prescription", "e-prescription", "e-prescribing”, "patient safety", and "hospital". Inclusion criteria were full text articles and English. Exclusion criteria were non-systematic review, literature review or narrative review, inaccessible, and not focused on patient safety. A total of 10.852 abstracts were obtained by searched database. After review process, 7 were finally retained in this review.

Results: Seven articles stated that e-prescriptions increased patient safety in hospital. E-prescribing had several advantages including (1) eliminates errors in handwriting and dispensing; (2) provide access patient prescription history; and (3) avaibility of patient's documented allergies to prevent negative reaction.

Conclusions: The e-prescription increases patient safety in hospital. E-prescribing has several advantages including (1) eliminates errors in handwriting and dispensing; (2) provide access patient prescription history; and (3) avaibility of patient's documented allergies to prevent negative reaction.
\end{abstract}

Keywords: electronic prescription, e-prescription, e-prescribing, patient safety, hospital.

Correspondence:

Farida Apriani Utami, Universitas Indonesia, Depok, West Java. Email: Farida.apriani@ui.ac.id. Mobile: 08129659076.

\section{BACKGROUND}

Concerns about patient safety and quality improvement in health care in patients have increased lately. There is an increasing use of technology in health care, specifically the use of electronic health records (EHR) or electronic medical records (EMR). Redesigning the current health care system involves the use of electronic health records (EHRs).
EHRs support evidence-based practice and improve the outcomes of patient care. Data can be taken from the HER system to examine patient populations, manage chronic diseases, and ensure the application of preventive care in a way that cannot be done with paper documentation (manual). This technology is predicted to be the future of clinical practice.

The $6^{\text {th }}$ International Conference on Public Health Best Western Premier Hotel, Solo, Indonesia, October 23-24, 2019 | 347

https://doi.org/10.26911/the6thicph-FP.04.17 
The history of patient care clinical documentation is based on a paper based system. Paper-based medical records are paper-based complicated, misplaced, inefficient, and sometimes ineffective. Collection of patient history and data is often overwhelming.

Inaccuracies in poor interdisciplinary documentation and communication result in medical errors. The EHR has reduced the number of medical errors through the supervision of clinical provider entry orders and electronic prescription drugs.

Electronic prescribing system (eprescribing) is a prescribing system using software designed to facilitate the prescripttion of drug services from the prescribing stage, the transcribing stage (the recipe reading for the dispensing process), the dispensing stage (preparation to prescription submission) by officers), the administration stage (the process of using drugs) and the monitoring process (Hahn and Lovett 2014).

E-Prescribing is a recipe that is transmitted using electronic media, and connects various information between doctors, eprescribing devices, pharmacies, financial departments, or health plans either directly or indirectly. E-prescribing not only transmits information in two directions between doctors and e-prescribing devices, but also transmits and combines electronic record systems known as Electronic Health Records (EHR) Systems (Pratiwi and Lestari, 2013).

In 2013, the e-prescription market was valued at more than $\$ 250$ million and was expected to reach a yield of $\$ 888$ million in 2019, a growth rate of 23.5 percent. Europe currently has a market share of the e-prescription market, but in North America, especially the United States, more than
$70 \%$ of doctors use e-prescriptions and $96 \%$ of pharmacies are connected to receive eprescriptions. Although these numbers are high, only $57 \%$ of all new and refilled prescriptions are being sent electronically and only $40 \%$ of states show a doctor's eprescription rate above 70\% (with 3 states of Minnesota, Lowa and Massachussets above $95 \%$ ).

The four states with the highest number of recipes - California, Texas, New York, and Florida - are all below the national average for e-prescription. These figures show that although the growth rate between e-prescriptions is very impressive, there is still room for improvement.

At the most basic level, the e-prescription system functions as an electronic reference handbook. More sophisticated eprescription systems act as stand-alone prescription writers. They can create and refill prescriptions for individual patients, manage medicines, and view patient history, connect to pharmacies or other dispensing outlets, and integrate with an electronic medical record system.

A preliminary study examining information automation shows that patients treated in hospitals that rank highest in the use of health information technology to manage patient records and doctor records are $15 \%$ less likely to die compared to patients in lower ranked hospitals. EHRS was found to offer the potential to provide efficient medical practice and cost savings. So, there is also evidence of early success. According to a national survey of doctors who have fulfilled all phases of the Centers of Medicare \& Medicaid Services (CMS) Electronic Health Care Incentive Program, $79 \%$ of providers report that, with HER, their practice functions more efficiently, 
and $82 \%$ report that sending prescriptions electronically (electronic recipe) saves time.

Electronic prescribing, or e-prescribing, describes health care providers or the ability to send prescription information electronically to pharmacies. Because eprescription eliminates the need for handwriting and fax prescription writing, there is little risk of errors about prescription or inaccurate dosing.

The nature of the e-prescription system can alert physicians and pharmacists about interactions of dangerous drugs, alternative generics, and patient insurance authorization requirements. Because doctors have complete patient information available electronically when prescribing, better decisions can be made about the most effective treatments. Some electronic systems can also notify the doctor when the patient has taken a prescription, allowing the doctor to monitor patients with medication.

A qualified e-prescribing system must be able to send prescriptions electronically, warn receptors about potential allergic reactions and notify physicians about generic alternatives, among other functions. Electronic prescribers also reduce the number of prescription errors caused by poor handwriting or faxing unreadable.

\section{SUBJECTS AND METHOD}

\section{Study Design}

Systematic Review starts with a data search consisting of research publications. We searched for online journals namely ProQuest, Cochrane Library, PubMed and Scopus to identify relevant scientific journals that were included in this review. A search was conducted to obtain full text articles and research abstract articles from 2014 to 2019. This review was carried out in accordance with the Preferred Reporting Items for Systematic Reviews and PRISMA guidelines.

\section{Inclusion and Exclusion Criteria}

The selection of inclusion criteria in this review are articles with qualitative methods (observations, semi-structured interviews, group discussions), including articles reporting mixed-study studies where qualitative substantive findings are presented, and also articles which are accessible and have the same conclusion focuses on patient safety. The following study exclusion criteria were issued: articles with systematic reviews, literature reviews, narrative reviews, or comments, quantitative methods, mixedmethods studies without substantive qualitative data or findings, studies that did not focus on patient safety and, studies evaluating interventions for improve safety.

\section{Data Extraction}

The articles were collected using keywords of "electronic prescription" OR "e-prescription" OR "e-prescribing", combined with the words "patient safety" AND "hospital". The terms are searched for as keywords and subject to the appropriate database. Only one writer independently filtered the complete text of all selected abstracts.

\section{RESULTS}

There are 10,852 abstracts identified from electronic databases (ProQuest, Cochrane, Scopus, and PubMed). We searched from full-text journals and found 9,334 articles. Then full-text journals were screened and restricted to scientific journals, in English, and using subjects namely electronic prescribing, prescriptions, patient safety and hospital, and we got 193 articles with a duplicate of 2 articles. Exclusion criteria were used after this, namely for SR articles, 
review literature or narrative review, which were not accessible and publications that did not focus on patient safety, and we found 26 publications. 26 publications were reviewed based on inclusion criteria and in the end 7 studies were reviewed. 6 studies were conducted using qualitative studies and one using mixed-methods (qualitative and quantitative).
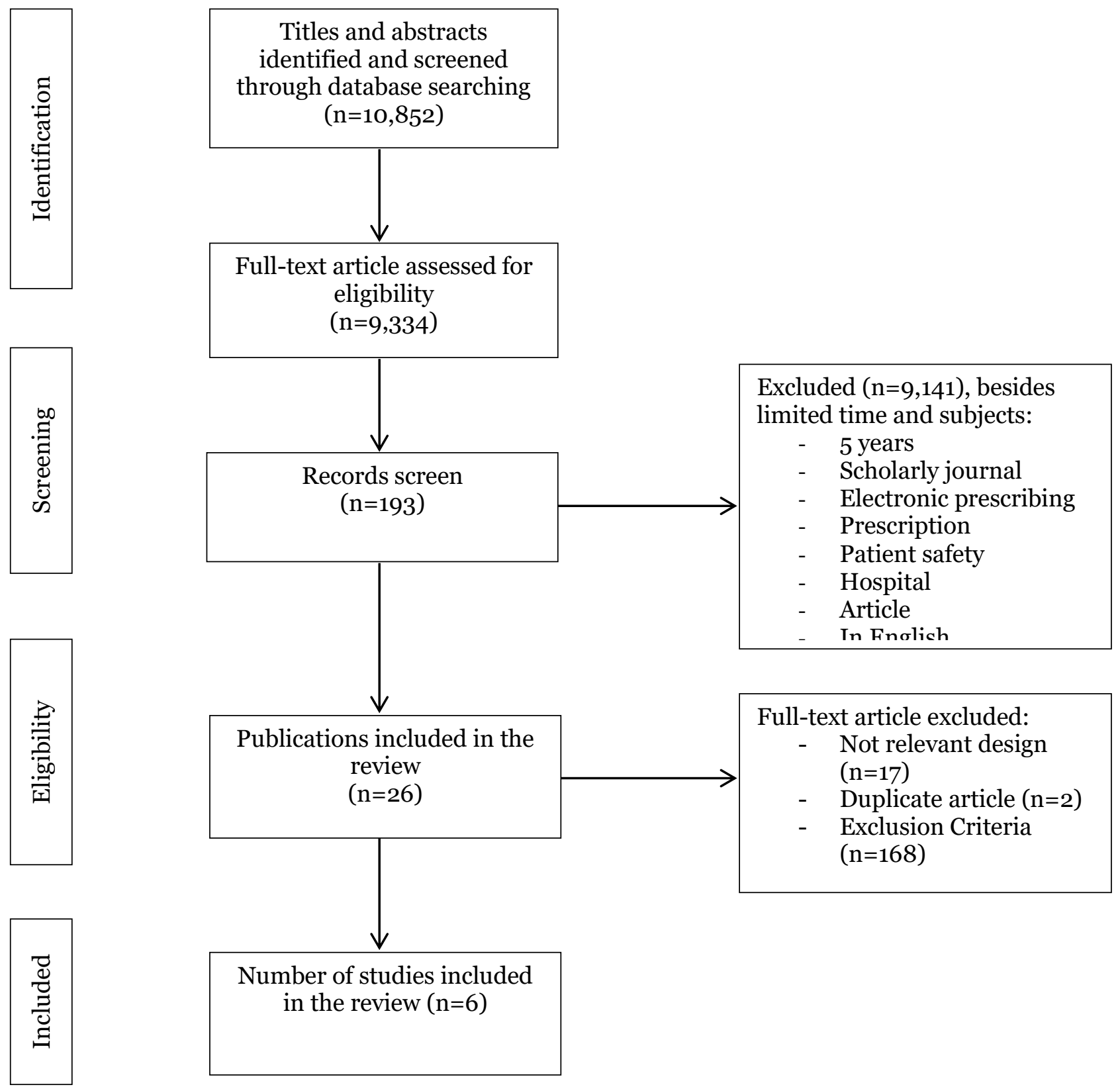

Figure 1. PRISMA Flow Diagram

The $6^{\text {th }}$ International Conference on Public Health Best Western Premier Hotel, Solo, Indonesia, October 23-24, 2019 | 350 
Table 1. Data Extraction Results

\begin{tabular}{|c|c|c|c|c|c|}
\hline No. & $\begin{array}{c}\text { Author } \\
\text { (Year) }\end{array}$ & Title & $\begin{array}{c}\text { Study } \\
\text { Design }\end{array}$ & Results & Conclusion \\
\hline 1. & $\begin{array}{l}\text { Odukoya et al. } \\
\text { (2015) }\end{array}$ & $\begin{array}{l}\text { The Hidden } \\
\text { Role of } \\
\text { Community } \\
\text { Pharmacy } \\
\text { Technicians in } \\
\text { Ensuring } \\
\text { Patient Safety } \\
\text { with the Use of } \\
\text { E-Prescribing }\end{array}$ & $\begin{array}{l}\text { A qualitative } \\
\text { study that } \\
\text { used } \\
\text { observations, } \\
\text { interviews, } \\
\text { and focus } \\
\text { groups to } \\
\text { understand } \\
\text { the role of } \\
\text { pharmacy } \\
\text { technicians } \\
\text { in e- } \\
\text { prescribing. }\end{array}$ & $\begin{array}{l}\text { Pharmacy technicians } \\
\text { were primarily } \\
\text { responsible for all } \\
\text { steps leading up to } \\
\text { pharmacist review of } \\
\text { the e-prescription and } \\
\text { dispensing of } \\
\text { medications to the } \\
\text { patient. Technician } \\
\text { characteristics, } \\
\text { including experience, } \\
\text { certification status, } \\
\text { and knowledge of } \\
\text { appropriate } \\
\text { medication use, were } \\
\text { reported as important } \\
\text { factors in supporting a } \\
\text { pharmacist's role in } \\
\text { ensuring patient } \\
\text { safety with the use of } \\
\text { e-prescribing. }\end{array}$ & $\begin{array}{l}\text { Pharmacy } \\
\text { technicians have } \\
\text { an important role } \\
\text { in supporting } \\
\text { pharmacists to } \\
\text { prevent } \\
\text { medication errors. } \\
\text { Certain } \\
\text { characteristics of } \\
\text { pharmacy } \\
\text { technicians were } \\
\text { identified with the } \\
\text { potential to } \\
\text { improve the e- } \\
\text { prescription } \\
\text { medication } \\
\text { dispensing process } \\
\text { and decrease } \\
\text { patient harm } \\
\text { through the } \\
\text { identification and } \\
\text { resolution of } \\
\text { errors. }\end{array}$ \\
\hline 2. & $\begin{array}{l}\text { Mills et al. } \\
\text { (2017) }\end{array}$ & $\begin{array}{l}\text { Hospital staff } \\
\text { views of } \\
\text { prescribing and } \\
\text { discharge } \\
\text { communication } \\
\text { before and after } \\
\text { electronic } \\
\text { prescribing } \\
\text { system } \\
\text { implementation }\end{array}$ & $\begin{array}{l}\text { Semi- } \\
\text { structured } \\
\text { face-to-face } \\
\text { qualitative } \\
\text { interviews } \\
\text { transcribed } \\
\text { verbatim and } \\
\text { coded using } \\
\text { the } \\
\text { Framework } \\
\text { Approach. }\end{array}$ & $\begin{array}{l}\text { Nineteen hospital } \\
\text { staff (consultant } \\
\text { doctors, junior } \\
\text { doctors, pharmacists } \\
\text { and advanced nurse } \\
\text { practitioners) } \\
\text { participated before } \\
\text { and after } \\
\text { implementation. } \\
\text { TDF domains relevant } \\
\text { to staff behavioral } \\
\text { determinants } \\
\text { preimplementation } \\
\text { were knowledge (task } \\
\text { or environment); } \\
\text { skills (competence); } \\
\text { social/professional } \\
\text { roles and identity; } \\
\text { beliefs about } \\
\text { capabilities; } \\
\text { environmental context } \\
\text { and resources } \\
\text { (including incidents). } \\
\text { An additional two } \\
\text { were relevant post- } \\
\text { implementation: }\end{array}$ & $\begin{array}{l}\text { HEPMA } \\
\text { implementation } \\
\text { produced } \\
\text { perceptions of } \\
\text { patient safety } \\
\text { improvement. TDF } \\
\text { use enabled } \\
\text { behavior change } \\
\text { analysis due to } \\
\text { implementation, } \\
\text { for example, staff } \\
\text { adoption of } \\
\text { behaviors to } \\
\text { ensure general } \\
\text { practitioners } \\
\text { receiv3.e good } \\
\text { quality discharge } \\
\text { information. }\end{array}$ \\
\hline
\end{tabular}

The $6^{\text {th }}$ International Conference on Public Health 


\begin{tabular}{|c|c|c|c|c|c|}
\hline & & & & $\begin{array}{l}\text { social influences and } \\
\text { behavioral regulation } \\
\text { (including self- } \\
\text { monitoring) }\end{array}$ & \\
\hline 3 & $\begin{array}{l}\text { Jeffries et al. } \\
\text { (2017) }\end{array}$ & $\begin{array}{l}\text { Understanding } \\
\text { the } \\
\text { implementation } \\
\text { and adoption of } \\
\text { an information } \\
\text { technology } \\
\text { intervention to } \\
\text { support } \\
\text { medicine } \\
\text { optimization in } \\
\text { primary care: } \\
\text { qualitative } \\
\text { study using } \\
\text { strong } \\
\text { structuration } \\
\text { theory }\end{array}$ & $\begin{array}{l}\text { Qualitative } \\
\text { design }\end{array}$ & $\begin{array}{l}\text { The ways in which the } \\
\text { EMOS was } \\
\text { implemented and } \\
\text { adopted were } \\
\text { conceptualized in four } \\
\text { broad thematic } \\
\text { categories: adoption } \\
\text { of the system for } \\
\text { information } \\
\text { gathering, perceptions } \\
\text { of the system as new, } \\
\text { perceptions of the } \\
\text { EMOS as requiring } \\
\text { technical competence } \\
\text { and the interactions } \\
\text { and relationships that } \\
\text { involved individual or } \\
\text { collective use of the } \\
\text { technology }\end{array}$ & $\begin{array}{l}\text { The dynamic } \\
\text { combination of } \\
\text { external, internal } \\
\text { and technological } \\
\text { structures } \\
\text { affected the } \\
\text { adoption and } \\
\text { implementation of } \\
\text { the system. } \\
\text { IT interventions } \\
\text { for medicine } \\
\text { optimisation } \\
\text { should consider } \\
\text { how utilisation } \\
\text { may depend on a } \\
\text { combination of the } \\
\text { infrastructure } \\
\text { 'within' primary } \\
\text { care, the social } \\
\text { structures } \\
\text { embedded in the } \\
\text { technology and the } \\
\text { conventions, } \\
\text { norms and } \\
\text { dispositions of } \\
\text { those utilizing it. }\end{array}$ \\
\hline 4. & $\begin{array}{l}\text { Furusa and } \\
\text { Coleman } \\
(2017)\end{array}$ & $\begin{array}{l}\text { Factors } \\
\text { influencing e- } \\
\text { health } \\
\text { implementation } \\
\text { by medical } \\
\text { doctors in } \\
\text { public hospitals } \\
\text { in Zimbabwe }\end{array}$ & $\begin{array}{l}\text { Qualitative } \\
\text { study }\end{array}$ & $\begin{array}{l}\text { the implementation of } \\
\text { e-health by medical } \\
\text { doctors in public } \\
\text { hospitals in Zimbabwe } \\
\text { is influenced by both } \\
\text { internal and external } \\
\text { factors. Internal } \\
\text { factors } \\
\text { include ICT } \\
\text { infrastructure and e- } \\
\text { health technologies, } \\
\text { ICT skills and } \\
\text { knowledge, technical } \\
\text { support, security } \\
\text { concerns, lack of basic } \\
\text { medical facilities, } \\
\text { demographic factors } \\
\text { such as age } \\
\text { and doctor-patient } \\
\text { relationship. External } \\
\text { factors are health } \\
\text { policy, funding and } \\
\text { bureaucracy }\end{array}$ & $\begin{array}{l}\text { A great potential } \\
\text { for implementing } \\
\text { e-health in } \\
\text { Zimbabwe if } \\
\text { internal and } \\
\text { external factors } \\
\text { are taken into } \\
\text { consideration. } \\
\text { Otherwise, } \\
\text { Zimbabwe will } \\
\text { continue to lag } \\
\text { behind in the } \\
\text { implementation of } \\
\text { e-health systems } \\
\text { in public hospitals }\end{array}$ \\
\hline
\end{tabular}




\begin{tabular}{|c|c|c|c|c|c|}
\hline 5. & $\begin{array}{l}\text { Ahmed et al. } \\
\text { (2018) }\end{array}$ & $\begin{array}{l}\text { Qualitative } \\
\text { study exploring } \\
\text { the } \\
\text { phenomenon of } \\
\text { multiple } \\
\text { electronic } \\
\text { prescribing } \\
\text { systems within } \\
\text { single hospital } \\
\text { organizations }\end{array}$ & $\begin{array}{l}\text { Used an a } \\
\text { priori } \\
\text { framework to } \\
\text { guide and } \\
\text { analyses } \\
\text { semi- } \\
\text { structured } \\
\text { interviews }\end{array}$ & $\begin{array}{l}\text { used an a priori } \\
\text { framework to guide } \\
\text { and analyse semi- } \\
\text { structured interviews. } \\
\text { Three co-existing } \\
\text { models of EP systems } \\
\text { adoption in hospitals } \\
\text { were identified: } \\
\text { organization-led, } \\
\text { clinician-led and } \\
\text { clinical network-led, } \\
\text { which may have } \\
\text { contributed to } \\
\text { multiple systems use. }\end{array}$ & $\begin{array}{l}\text { In the near to mid- } \\
\text { term future, } \\
\text { multiple EP } \\
\text { systems use is } \\
\text { likely to remain in } \\
\text { place, which } \\
\text { creates challenges } \\
\text { for the NHS } \\
\text { workforce and for } \\
\text { patient safety. }\end{array}$ \\
\hline 6 & $\begin{array}{l}\text { McLeod et al. } \\
\text { (2019) }\end{array}$ & $\begin{array}{l}\text { The impact of } \\
\text { implementing a } \\
\text { hospital } \\
\text { electronic } \\
\text { prescribing and } \\
\text { administration } \\
\text { system on } \\
\text { clinical } \\
\text { pharmacists' } \\
\text { activities - A } \\
\text { mixed methods } \\
\text { study }\end{array}$ & $\begin{array}{l}\text { Mixed } \\
\text { methods } \\
\text { design. This } \\
\text { design } \\
\text { enables } \\
\text { quantitative } \\
\text { results to be } \\
\text { explained } \\
\text { using } \\
\text { qualitative } \\
\text { methods. }\end{array}$ & $\begin{array}{l}\text { Observations totaled } \\
116 \mathrm{~h} \text { and } 50 \text { min. } \\
\text { Seven main themes } \\
\text { were identified from } \\
\text { the interviews, } \\
\text { underpinned by a core } \\
\text { explanatory concept } \\
\text { around the enhanced } \\
\text { and shifting role of the } \\
\text { ward pharmacist post- } \\
\text { ePA. Pharmacists } \\
\text { perceived there to be a } \\
\text { number of valuable } \\
\text { safety features with } \\
\text { ePA. }\end{array}$ & $\begin{array}{l}\text { Pharmacists may } \\
\text { spend less time } \\
\text { with patients with } \\
\text { ePA. Pharmacists } \\
\text { valued a number } \\
\text { of safety features } \\
\text { associated with } \\
\text { ePA but also } \\
\text { perceived an } \\
\text { overall increase in } \\
\text { medication risk. }\end{array}$ \\
\hline
\end{tabular}

\section{DISCUSSION}

Semi-structured interviews to gather additional information are a good way to research, because the questions in the interview guide are designed to be neutral and open to keep from developing socially desired responses. The research findings conducted in the USA show that all steps in entering and submitting e-prescription processing phases are usually carried out by pharmacy technicians before verification by a pharmacist.

The pharmacist's review of the e-prescription consists of verification as follows: (1) information entered by the input technician, (2) the appropriate drugs filled out by the technician, (3) drug interactions, (4) dose changes, and (5) a history of the patient's overall treatment profile. Finally, the pharmacist gets a prescription and starts advising the patient before giving the medicine to the patient (patient counseling and drug expenditure).

Pharmacists report that person-specific characteristics, such as experience, certification, commitment, critical thinking skills, attention to details, proactive personality, and full-versus part-time status, affect how well the technician can carry out patient care responsibilities. This association can have an influence on the implications of clinical outcomes, such as perfor- 
mance or accuracy in processing e-prescriptions, identification of medication errors, and efficiency in resolving errors when they occur. Positive implications of this include fewer prescriber, pharmacist and technician time to resolve medication errors and fewer medication errors that might reach the patient and cause danger (Odukoya et al., 2015).

While study conducted in the UK, explains the complexity of prescription drugs and communication of discharge information using the Hospital Electronic Prescribing and Medicine Administration (HEPMA) system from the user's perspective. That an increase in patient safety is claimed to have occurred because of the complete readability of the prescription, accurate documenttation of drug administration, and the availability of decision support information (Mills et al., 2017).

In studies in the USA and UK conducted in the pharmaceutical community, because in previous studies found as much as $11 \%$ of e-prescribing received at community pharmacies have medication errors. Findings from this study highlight the role of pharmacy technicians in processing electronic prescriptions in pharmacies (Odukoya et al., 2015).

Adoption and implementation of the Electronic Medical Optimization System (EMOS) depends on the dynamic mix of external structures, internal structures, and material properties embedded in technology (Jeffries et al., 2017).

Having several electronic prescription systems is considered to have several advantages, especially in the context of systems used in niche clinical specialties (Ahmed et al., 2018). Much of the previous studies on interventions to improve treatment safety has focused on secondary health care settings and electronic audits (Jeffries et al., 2017).

The implementation of an electronic prescribing system is recommended to improve patient safety and doctor / practitioner information communication. Pharmacists have proven to play an important role in the electronics front. High attention to detail is important for technicians to contribute to improving patient safety. Pharmacy technicians have a general awareness of what is happening at the pharmacy. For instance, usually the first set of eyes to review e-prescriptions and to detect errors.

E-prescribing can eliminate handwritten errors or illegibility and also gives doctors and pharmacists access to a patient's prescription history to reduce errors or the possibility of incorrect medication being issued. E-prescribing gives the doctor full visibility into all patient allergy documenttation and previously prescribed medications and will trigger clinical warnings if newly prescribed drugs have the potential for negative reactions.

Warnings in the system will notify prescribers if allergies, interactions with other drugs the patient is taking, duplicate therapy, as well as pediatric, pregnancy and geriatric problems that will prevent patients from taking certain medications. E-prescribing eliminates suspicion by encouraging prescribers to fill doses, routes, strength and frequency and providing drop-down lists of the most common sig information. It also includes dosage checking and duplicate therapy alerts.

In Indonesia, this electronic prescription has been widely applied and is highly recommended for use in prescribing doctors in hospitals. This has been proven to have benefits in medication safety and will certainly affect patient safety, although it 
still needs additional support systems to further enhance the benefits of electronic prescribing, so that the completeness of the system is expected to encourage doctors to utilize electronic prescription systems (Susi et al., 2014).

\section{REFERENCES}

Pratiwi PS, Lestari A (2013). E-prescribing: studi kasus perancangan dan implementasi sistem resep obat apotik klinik (E-prescribing: a case study of the design and implementation of a clinical pharmacy prescription system). Indonesian Jurnal on Computer Science-Speed (IJCSS). 10(4): 9-14.

Hahn A, Lovett A (2014). Electronic prescribing: An examination of cost effecttiveness, clinician adoption and limitations, Universal Journal of Clinical Medicine, 2(1): 1-24.

Ahmed Z, Jani Y, Franklin BD (2018). Qualitative study exploring the phenomenon of multiple electronic prescribing systems within single hospital organisations, BMC Health Services Research, 18(1): 1-12. doi: 10.1186/s12913-018-3750-1.

Furusa SS, Coleman A (2018). Factors influencing e-health implementation by medical doctors in public hospitals in Zimbabwe, SA Journal of Information Management, 2O(1): 1-10. doi: 10.4102/sajim.v20i1.928.

Jeffries M, Phipps D, Howard RL , Avery A, Rodgers S, Ashcroft D (2017). Under- standing the implementation and adoption of an information technology intervention to support medicine optimization in primary care: Qualitative study using strong structuration theory, BMJ Open, 7(5). doi: 10.1136/bmjopen-2016-014810.

McLeod M et al. (2019) The impact of implementing a hospital electronic prescribing and administration system on clinical pharmacists activities - A mixed methods study, BMC Health Services Research, 19(1): 1-12. doi: 10.1186/s12913-019-3986-4.

Mills PR, Weidmann AE, Stewart D (2017). Hospital staff views of prescribing and discharge communication before and after electronic prescribing system implementation, International Journal of Clinical Pharmacy. Springer International Publishing, 39(6): 13201330. doi: 10.1007/s11096-017-05432.

Odukoya O, Schleiden L, Chui M (2015). The Hidden Role of Community Pharmacy Technicians in Ensuring Patient Safety with the Use of E-Prescribing, Pharmacy, 3(4): 330-343. doi: 10.3390/pharmacy3040330.

Susi M et al. (2014). Peran resep elektronik dalam meningkatkan medication safety Pada Proses Peresepan (The Role of Electronic Prescriptions in Improving Medication Safety in the Prescribing Process), 17(01): 30-36. 